\title{
Addressing information gaps in wild-caught foods in the US: Brook trout nutritional analysis for inclusion into the USDA national nutrient database for standard reference
}

\author{
Moira M. Tidball ${ }^{\mathrm{b}, *}$, Jacob Exler ${ }^{\mathrm{c}}$, Meena Somanchi ${ }^{\mathrm{c}}$, Juhi Williams ${ }^{\mathrm{c}}$, Clifford Kraft ${ }^{\mathrm{a}}$, \\ Paul Curtis ${ }^{\mathrm{a}}$, Keith G. Tidball ${ }^{\mathrm{a}}$

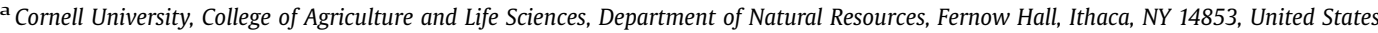 \\ ${ }^{\mathrm{b}}$ Cornell Cooperative Extension Seneca County, 308 Main Street Shop Centre, Waterloo, NY, 13165-1455, United States \\ ${ }^{\mathrm{c}}$ Nutrient Data Laboratory, ARS/USDA/BHNRC, 10300 Baltimore Avenue Bldg. 005 Room. 215, BARC West, Beltsville, MD 20705, United States
}

\section{A R T I C L E I N F O}

\section{Article history:}

Received 28 July 2016

Received in revised form 7 March 2017

Accepted 10 March 2017

Available online 16 March 2017

\section{Keywords:}

Wild-caught

Brook trout

Nutrients

Nutrition

Food composition

Food analysis

\section{A B S T R A C T}

Motivations for seeking local food include eating foods for quality, nutritional value, ethics and environmental concerns. Wild foods, such as wild game and fish, are increasingly included as a local food source, yet many legally procured species of wild game and fish lack knownnutrition information in the USDA National Nutrient Database for Standard Reference (SR). Among those species that lack nutrition information are brook trout. The research team worked with the Nutrient Data Laboratory (NDL) within USDA to develop a collection protocol for brook trout. Using legal angling techniques, samples were collected in the Adirondack region of New York State during the months of May and June 2012 by members of the research team. The trout were processed according to USDA determined dissection protocols to attain edible meat portions. Nutrient analysis was conducted on raw brook trout meat samples at USDA appointed commercial laboratories for proximates, calcium, iron, magnesium, phosphorus, potassium, sodium, zinc, riboflavin, niacin, thiamin, Vitamin B6, Vitamin B12, individual fatty acids, and cholesterol. Analytical data was sent to NDL at USDA, where it was reviewed, compiled and published in SR. Nutrient values were determined by validated laboratories using quality assurance procedures. Full nutrient profiles were made available in SR.

(c) 2017 Elsevier Inc. All rights reserved.

\section{Introduction}

Though the Dietary Guidelines for Americans suggest choosing lean meats and consuming more seafood as a protein source (U.S. Department of Agriculture and U.S. Department of Health and Human Services, 2010), and thoughe consumers are interested in knowing the nutritional content of meat choices, along with how to prepare it (Rimal, 2005; Ballin, 2010)., only 38\% of wild game and fish species that are legal to hunt in New York state haveknown nutritional data, leaving 42 species of regulated fish and game existing in New York that have incomplete or no nutrition

\footnotetext{
* Corresponding author.

E-mail addresses: mmt65@cornell.edu (M.M. Tidball),jacob.exler@ars.usda.gov (J. Exler), meena.somanchi@ars.usda.gov (M. Somanchi), juhi.williams@ars.usda.gov (J. Williams),cek7@cornell.edu (C. Kraft), pdc1@cornell.edu (P. Curtis), kgtidball@cornell.edu (K.G. Tidball).
}

information available (Tidball et al., 2014a, 2014b). According to our own anecdotal evidence and analysis, and via reasonable extrapolation, the same is true for most if not all other states in the US.

Recognizing this informational gap and the clear opportunity for meaningful empirical and applied research, our hypothesis was that a nutritional analysis would yield meaningful differences between wild caught species and domestic versions. We also recognized a rare opportunity to contribute basic data and analysis to a much-used scientific resource. Thus, we applied for and received USDA funding to collect and analyze the nutritional content of wild species for purposes of comparison, and for addition of these species in SR. Brook trout was selected as our initial study because of their prized status as a fish inhabiting cold clean and pristine waters such as those found in the Adirondacks, and because the brook trout is the New York state fish. Other species selected and sampled for future studies include Canada 
goose and ruffed grouse. Here we will focus on the brook trout study.

\subsection{Brook trout}

Brook trout, (Salvelinus fontinalis), belong to the salmonine subfamily of the family of fishes known as the salmonidae. This family includes numerous fishes throughout the world that are prized for their culinary characteristics, such as various species of salmon, trout and whitefish. It's useful to recognize that other names are often used for this species, including the names "speckled trout" or "brook char"(Scott and Crossman, 1973). Most anglers refer to this species as brook trout, which is reflected in the use of that name by nine states that have designated this as their state fish, including New York where the samples were collected. Brook trout are notable for their beauty and their former abundance in cold streams and lakes throughout the north temperate region of North America. The brook trout is highly valued by anglers, conservationists, and managers throughout its native range in eastern North America, though ironically, this fish is considered to be a nuisance invader in the western U.S. because it outcompetes native cutthroat trout (Dunham et al., 2002). Brook trout are extremely sensitive to declining water quality, introductions of non-native predators and habitat degradation (Nislow and Lowe, 2003). Acidification of lakes and streams in both the Adirondack mountain region of New York and the southern Appalachian mountains has diminished many brook trout populations. In addition, brook trout are considered to be particularly vulnerable to the negative effects of climate change, therefore recent conservation efforts have been implemented to sustain existing populations in their native range. The diet and feeding behavior of brook trout have been described by many investigators. Ricker (1930) provided one the earliest thorough descriptions of brook trout diets and listed over 80 genera of aquatic invertebrates, over 30 families of terrestrial insects, and at least 24 species of crustaceans and mollusks, and several species of fish, amphibians, and reptiles consumed by brook trout in Ontario. Other reviews of brook trout food habits show that brook trout are opportunistic predators able to consume a wide variety of prey types (Carlander, 1969; Scott and Crossman, 1973; Power, 1980). Overall, these diet studies indicate that brook trout consume the types of prey typically consumed by fishes that people prefer to eat. Brook trout are prized by some as a culinary delight because of their pinkish-orange flesh, a trait shared with some of their salmonidae relatives, particularly Chinook salmon (Oncorhynchus tshawytscha) and brown trout (Salmo Trutta). Aquatic scientists and biologists attribute this flesh color in salmon to the presence of krill in their diet, which contain carotenoid pigments (Steven, 1948; Goodwin, 1986; Torrissen et al., 1989). Through genetic interactions, these pigments appear in the muscle tissue of Chinook salmon (for general discussion of these phenomenon, see Love, 2011; Ray, 2014). One could argue a similar process is occurring with brook trout, and that the carotenoids are being acquired via terrestrial (Feltwell and Rothschild, 1974) and aquatic (Czeczuga

Table 1

Brook trout sample weights from the Adirondack Region of New York State, 2012.

\begin{tabular}{|c|c|c|c|c|c|c|c|c|}
\hline $\begin{array}{l}\text { Fish } \\
\#\end{array}$ & Location caught & Date & Original wgt. (g) & Field Clean refuse $(\mathrm{g})$ & $\begin{array}{l}\text { Dressed wgt. } \\
(\mathrm{g})\end{array}$ & Lab Refuse (g) & $\begin{array}{l}\text { Edible } \backslash \\
\text { Portion (g) }\end{array}$ & \% Edible Portion \\
\hline 1 & Location A & $5 / 8 / 12$ & 85.5 & 32 & 50.5 & 18 & 30.5 & 35.67 \\
\hline 2 & Location A & $5 / 8 / 12$ & 204 & 73.5 & 129 & 23 & 100.5 & 49.26 \\
\hline 3 & Location A & $5 / 7 / 12$ & 236 & 93 & 140 & 32 & 99 & 41.95 \\
\hline 4 & Location A & $5 / 7 / 12$ & 144.5 & 54 & 87.5 & 20.5 & 66 & 45.67 \\
\hline 5 & Location A & $5 / 7 / 12$ & 152 & 58 & 91 & 23.5 & 63.5 & 41.78 \\
\hline 6 & Location A & $5 / 10 / 12$ & 355 & 115.5 & 233.5 & 69 & 153 & 43.10 \\
\hline 7 & Location A & $5 / 10 / 12$ & 298 & 96.5 & 194.5 & 69 & 110.5 & 37.08 \\
\hline 8 & Location A & $5 / 10 / 12$ & 146 & 58 & 85 & 34 & 46 & 31.51 \\
\hline 9 & Location A & $5 / 11 / 12$ & 162 & 56 & 103.5 & 39.5 & 59 & 36.42 \\
\hline 10 & Location A & $5 / 11 / 12$ & 67.5 & 24 & 41.5 & 17.5 & 21.5 & 31.85 \\
\hline \multirow[t]{3}{*}{11} & Location A & $5 / 11 / 12$ & 337.5 & 102.5 & 230.5 & 64 & 161 & 47.70 \\
\hline & Mean & & 198.9 & & & & 82.8 & 40.18 \\
\hline & SE & & 29.3 & & & & 14.0 & 1.8 \\
\hline 12 & Location B & $5 / 12 / 12$ & 731 & 215 & 503.5 & 178.5 & 326.5 & 44.66 \\
\hline 13 & Location B & $5 / 12 / 12$ & 516.5 & 373 & 138 & 107.5 & 268 & 51.89 \\
\hline 14 & Location $\mathrm{B}$ & $5 / 12 / 12$ & 228 & 154.5 & 71.5 & 41 & 109 & 47.81 \\
\hline 15 & Location $\mathrm{B}$ & $5 / 12 / 12$ & 425.5 & 289 & 132 & 83 & 200 & 47.00 \\
\hline 16 & Location $\mathrm{B}$ & $5 / 12 / 12$ & 489 & 334 & 151 & 99 & 225.5 & 46.11 \\
\hline 17 & Location B & $5 / 12 / 12$ & 172.5 & 113.5 & 57.5 & 39 & 72 & 41.74 \\
\hline 18 & Location $\mathrm{B}$ & $5 / 12 / 12$ & 136 & 85.5 & 48 & 25.5 & 59 & 43.38 \\
\hline \multirow[t]{3}{*}{19} & Location $\mathrm{B}$ & $5 / 12 / 12$ & 257 & 177 & 76 & 49.5 & 124 & 48.25 \\
\hline & Mean & & 369.4 & & & & 173 & 46.4 \\
\hline & SE & & 72.7 & & & & 34.3 & 1.12 \\
\hline 20 & Location C & $6 / 24 / 12$ & 287 & $79.5^{*}$ & 207.5 & 62 & 138.5 & 48.26 \\
\hline 21 & Location C & $6 / 24 / 12$ & 379,5 & $120^{*}$ & 259.5 & 100 & 152.5 & 40.18 \\
\hline 22 & Location C & $6 / 24 / 12$ & 627 & $199^{*}$ & 428 & 137.5 & 282.5 & 45.06 \\
\hline 23 & Location C & $6 / 24 / 12$ & 530.5 & $172.5^{*}$ & 358 & 126 & 224 & 42.22432 \\
\hline 24 & Location C & $6 / 24 / 12$ & 525 & $152.5^{*}$ & 372.5 & 131.5 & 235 & 44.7619 \\
\hline 25 & Location C & $6 / 24 / 12$ & 661 & $229^{*}$ & 432 & 177.5 & 247.5 & 37.44327 \\
\hline 26 & Location C & $6 / 24 / 12$ & 183.5 & $52^{*}$ & 131.5 & 52.5 & 76 & 41.41689 \\
\hline 27 & Location C & $6 / 24 / 12$ & 175.5 & $50.5^{*}$ & 125 & 43 & 77.5 & 44.15954 \\
\hline 28 & Location C & $6 / 24 / 12$ & 596 & $180.5^{*}$ & 415.5 & 184.5 & 225 & 37.75168 \\
\hline \multirow[t]{3}{*}{29} & Location C & $6 / 24 / 12$ & 528 & $147^{*}$ & 381 & 155.5 & 219.5 & 41.57197 \\
\hline & Mean & & 449.3 & & & & 187.8 & 42.3 \\
\hline & SE & & 57.1 & & & & 22.8 & 1.1 \\
\hline
\end{tabular}

*Some field clean refuse weights include a small (6-23 g) sample piece needed for a different brook trout study.

Values are Mean \pm SE (Standard Error).

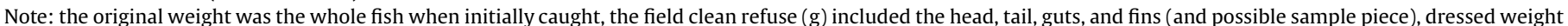
is the cleaned fish with skin and rib bones intact, lab refuse is the skin and rib bones removed from the fish, edible portion is meat only. 
and Mironiuk, 1979; Matsuno et al., 1999) insects (Heath et al., 2013) and crustaceans such as crayfish (Czeczuga and CzeczugaSemeniuk, 1999). Does this coloration play a factor in the nutritional content of the fish for human consumption? Astaxanthin is a carotenoid found in red-pigmented seafood, such as shrimp and salmon that has strong antioxidant properties and potential health benefits (Yamashita, 2013). Additional research is required to make any statements of certainty regarding the health benefits of carotenoids and brook trout consumption, but we can say that pigmentation adds a culinary appeal, as farmed fish is often altered to resemble the coloration of wild-caught fish to appeal to consumers, especially with salmon (Steine et al., 2005).

\subsection{Legibility of food-The white nutrition facts label}

An area for further investigation involves the extent to which nutrition labeling, and comprehension of that labeling, influences food choices, especially for wild-caught meats One study, using national USA survey data, showed a majority of respondents thought that it was very important that meat labels contain information regarding nutrition, ingredients, health claim, and production process, respectively this labeling information informed purchases of meat and consumption (Rimal, 2005). Our initial survey work (IRB protocol ID \# 1203002920) with stakeholders indicated $50 \%$ believed it is important or very important to have nutrition information available for recipes involving wild fish and game. Also, 36\% of respondents believed easy access to nutrition information would lead to an increase in their desire to eat wild fish and game meat (Tidball et al., 2014a, 2014b). Furthermore, $76 \%$ of respondents said nutrition and health factors were important determinants of wild fish consumption, with freshness, quality and taste rating the highest. We noted a degree of hesitancy among some study participants (often the spouses of hunters or anglers) when fish or game meat was presented for preparation. Reasons cited for this hesitancy included: 1 . The meat not being packaged and purchased in recognizable formats (white Styrofoam, plastic wrap, labeling), 2. Variation in expected color and texture, and assumptions about these variations as indicative of quality, and 3. The unknown factors about the meat (taste, nutrition content, food safety issues). A question to be addressed is, "Does the legibility and perceived normalcy of a certain food, especially wild fish or game meat, have an effect on pre-conceived notions and subsequent preparation and consumption choices?". Some people are classified as "neophobic" eaters who are unwilling to try new or unusual food (Veeck, 2010). Perhaps normalizing the meat by ensuring that consumers know it's nutritional content would make them more willing to accept it. Further discussion of this is warranted but beyond the scope of this particular study. Potential future work may require comparison of meat items that are labeled and unlabeled, but for which the nutritional content is

Table 2

Methods used for nutrient analyses of brook trout collected in New York State, 2012.

\begin{tabular}{|c|c|c|c|}
\hline Analyte & Method & Method Description & Reference citation for method details \\
\hline Moisture & Pressure Drying & Sample $(5-10 \mathrm{~g})$ dried under pressure at $70^{\circ} \mathrm{C}$ for $6 \mathrm{~h}$ & $\begin{array}{l}\text { AOAC (2011), } \\
\text { method 934.06 } \\
\text { (37.1.10) Moisture in } \\
\text { dried fruits }\end{array}$ \\
\hline Protein & $\begin{array}{l}\text { Combustion } \\
\text { determination of } \\
\text { nitrogen }\end{array}$ & $\begin{array}{l}\text { Nitrogen determined by a combustion-detection technique (Dumas method), with the } \\
\text { percent nitrogen converted to protein using a factor of } 6.25\end{array}$ & $\begin{array}{l}\text { AOAC (2011), } \\
\text { method } 968.06 \\
(4.2 .04), \text { Protein } \\
\text { (crude) in animal } \\
\text { feed }\end{array}$ \\
\hline Fat & Acid Hydrolysis & $\begin{array}{l}\text { Total fat determined gravimetrically after } \\
\text { acid hydrolysis and recovery of extractable fat using ether and hexane }\end{array}$ & $\begin{array}{l}\text { AOAC ( } 2011) \\
\text { method } 954.02 \\
\text { ( } 4.5 .02 \text { or } 7.063) \text { Fat } \\
\text { (crude) or ether } \\
\text { extract in pet food }\end{array}$ \\
\hline Niacin & Microbiological & $\begin{array}{l}\text { Sample hydrolyzed with sulfuric acid; } \mathrm{pH} \text { adjusted to remove interferences. Niacin } \\
\text { determined by comparing the growth response Lactobacillus plantarum using the } \\
\text { sample compared to the growth response for a niacin standard, measured } \\
\text { turbidimetrically }\end{array}$ & $\begin{array}{l}\text { AOAC (2011), } \\
\text { methods } 944.13 \\
(45.2 .04), 960.46 \\
(45.2 .01), \text { and } 985.34 \\
\text { (50.1.19), Niacin in } \\
\text { foods }\end{array}$ \\
\hline Vitamin B6 & Microbiological & $\begin{array}{l}\text { Sample hydrolyzed with dilute sulfuric } \\
\text { acid in an autoclave; pH adjusted to remove interferences. Vitamin B6 } \\
\text { determined by comparing the growth response of Saccharomyces } \\
\text { carlsbergenesis using the sample compared the growth response for a } \\
\text { vitamin B6 standard, measured turbidimetrically }\end{array}$ & $\begin{array}{l}\text { AOAC (2011), } \\
\text { method 961.15 } \\
(45.2 .08), \text { Vitamin } \\
\text { B6 (pyridoxine, } \\
\text { pyridoxal, and } \\
\text { pyridoxamine) in } \\
\text { food extracts }\end{array}$ \\
\hline Riboflavin & Fluorometric & $\begin{array}{l}\text { Sample autoclaved in dilute acid; } \mathrm{pH} \text { adjusted with } \mathrm{NaOH} \text {. Dilute } \mathrm{HCl} \text { added to } \\
\text { precipitate protein and the sample is filtered. Acetic acid and then } 4 \% \text { potassium } \\
\text { permanganate are added. Hydrogen peroxide is added to destroy the permanganate } \\
\text { color. Fluorescence is measured, } \mathrm{Na2S2O} 4 \text { added and fluorescence is measured again }\end{array}$ & $\begin{array}{l}\text { AOAC (2011), } \\
\text { method 970.65, Riboflavin (vitamin } \\
\text { B2) in foods and vitamin preparations }\end{array}$ \\
\hline Thiamin & Fluorometric & $\begin{array}{l}\text { Sample autoclaved in dilute acid to extract thiamin. Resulting solution incubated with } \\
\text { a buffered enzyme solution to release bound thiamin. Solution purified on an ion- } \\
\text { exchange column. Aliquot taken and reacted with potassium ferricyanide to convert } \\
\text { thiamin to thiochrome. Thiochrome extracted into isobutyl alcohol and read on a } \\
\text { fluorometer against a known standard }\end{array}$ & $\begin{array}{l}\text { AOAC (2011), } \\
\text { methods } 942.23 \\
(45.2 .05), 953.17 \\
\text { (45.1.06), and } 957.17 \\
\text { (45.1.07), Thiamine in bread }\end{array}$ \\
\hline $\begin{array}{l}\text { Elements (Ca, Mg, K, } \\
\text { Na, P, Cu, Fe, Mn, } \\
\mathrm{Zn})\end{array}$ & ICP & $\begin{array}{l}\text { Dry ashing }\left(500^{\circ} \mathrm{C} \pm 50^{\circ} \mathrm{C} \text { ) and dissolution in concentrated } \mathrm{HCl} \text {, or wet ashing }\right. \\
\text { (digestion in concentrated acid, with heat) of sample. Followed by appropriate } \\
\text { dilution, followed by quantitation of each element using an ICP spectrometer and } \\
\text { comparing the emission of the unknown sample against the emission of each element } \\
\text { in standard solutions }\end{array}$ & $\begin{array}{l}\text { AOAC (2011), } \\
\text { methods } 985.01 \\
\text { (3.2.06) and } 984.27 \\
\text { (50.1.15), Metals in food by ICP }\end{array}$ \\
\hline
\end{tabular}

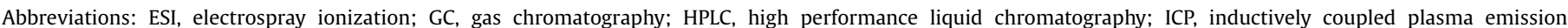
spectroscopy; ID, isotope dilution; LC, liquid chromatography; MS, mass spectrometry; TCEP, tris(2- carboxyethyl)phosphine. 
known. Therefore, we hope that this article will lay the groundwork for comparative studies regarding the extent to which labeling influences food choices associated with wild fish and game.

\section{Method}

\subsection{Materials and sampling}

The research team worked with the Nutrient Data Laboratory (NDL) within USDA to set up a collection protocol for brook trout (Appendix A). Two to three pounds of wild- caught, edible meat was collected. Using legal angling techniques (fly-fishing and spincasting) and artificial lures, samples were collected over a twomonth period during May and June 2012 by members of the research team. This time frame coincides with the time frame most anglers would target these fish. The trout were caught in the Adirondack region of New York State and positively identified as brook trout species by qualified fisheries scholars of the Department of Natural Resources at Cornel University. The trout were transported to field-located weighing and processing stations, and were initially weighed to the nearest $0.0 \mathrm{~g}$ weight. The trout were carefully dissected to remove the edible portion from the refuse without nicking the bone and affecting calcium content of the meat using USDA dissection protocols. The meat portions and refuse were weighed and recorded (Table 1). Only the edible portion of brook trout from the three sample locations were sent to the USDA appointed laboratory at Virginia Tech for compositing and homogenizing the meat to analyze the nutritional content. Nutrient analysis was done on raw brook trout at USDA appointed commercial laboratories for proximates (water, energy/total calorie, protein, total fat, ash, and carbohydrate), calcium, iron, magnesium, phosphorus, potassium, sodium, zinc, riboflavin, niacin, thiamin, Vitamin B6, Vitamin B12, individual fatty acids, and cholesterol. Analytical data from Virginia Tech were sent to NDL at USDA, where they was reviewed, compiled and released into SR. Nutrient values were determined by validated laboratories using quality assurance procedures. Full nutrient profiles were made available in SR (http://www.ars.usda.gov/nutrientdata). Samples of 29 wild brook trout were obtained from three locations in New York State. All samples were field dressed on site and initially dissected into edible portions and weighed at Cornell prior to being shipped on dry ice to the Food Analysis Laboratory and Control Center at Virginia Tech, where the samples were stored prior to being composited. Three composites were analyzed. Edible portions of all the fish collected at a given location were homogenized together to give one composite per location. This was necessary to provide sufficient material for analysis of the various nutrients. For each composite, $1.36 \mathrm{~kg}$ of edible portion material (meat-fillet) was needed. Composites were homogenized with liquid nitrogen, placed in jars under nitrogen, and stored frozen at $-65^{\circ} \mathrm{C}$ until they were shipped to commercial analytical laboratories, pre-approved for participation in the National Food and Nutrition Analysis Program (NFNAP), for analysis. Composited samples were analyzed for a complete nutrient profile, including fat and fatty acids using Association of Official Analytical Chemists (AOAC) or other acceptable methods (Table 2). Certified reference materials and in- house prepared control materials were also shipped to monitor the analyses done by the laboratories (Phillips et al., 2006). The nutrient data were compiled and released into SR26 to provide current and accurate data for these foods.

\subsection{Analytical methods}

Macronutrients, vitamins, and minerals were assayed. Standard and/or published methods were used, consistent with the methods of analysis for other foods in the USDA National Food and Nutrient Analysis Program (NFNAP) (Haytowitz et al., 2008). Samples of

Table 3

Brook Trout Nutrition Information in SR.

\begin{tabular}{|c|c|c|c|c|}
\hline Nutrient & Unit & Value per $100 \mathrm{~g}$ & 1 filet $149 \mathrm{~g}$ & 1 fish $332 \mathrm{~g}$ \\
\hline Water & g & 75.67 & 112.75 & 251.22 \\
\hline Energy & $\mathrm{kJ}$ & 458 & 682 & 1521 \\
\hline Protein & g & 21.23 & 31.63 & 70.48 \\
\hline Total lipid (fat) & $\mathrm{g}$ & 2.73 & 4.07 & 9.06 \\
\hline Carbohydrate, by difference & $\mathrm{g}$ & 0.00 & 0.00 & 0.00 \\
\hline Calcium, Ca & $\mathrm{mg}$ & 25 & 37 & 83 \\
\hline Iron, $\mathrm{Fe}$ & $\mathrm{mg}$ & 0.38 & 0.57 & 1.26 \\
\hline Magnesium, Mg & $\mathrm{mg}$ & 28 & 42 & 93 \\
\hline Phosphorus, $\mathrm{P}$ & $\mathrm{mg}$ & 246 & 367 & 817 \\
\hline Potassium, K & $\mathrm{mg}$ & 417 & 621 & 1384 \\
\hline Sodium, Na & $\mathrm{mg}$ & 454 & 67 & 149 \\
\hline Zinc, $\mathrm{Zn}$ & $\mathrm{mg}$ & 0.55 & 0.82 & 1.83 \\
\hline Thiamin & $\mathrm{mg}$ & 0.137 & 0.204 & 0.455 \\
\hline Riboflavin & $\mathrm{mg}$ & 0.101 & 0.150 & 0.335 \\
\hline Niacin & $\mathrm{mg}$ & 5.293 & 7.887 & 17.573 \\
\hline Vitamin B-6 & $\mathrm{mg}$ & 0.273 & 0.407 & 0.906 \\
\hline Vitamin B-12 & $\mu g$ & 2.77 & 4.13 & 9.20 \\
\hline Fatty acids, total saturated & g & 0.595 & 0.887 & 1.975 \\
\hline Fatty acids, total monounsaturated & $\mathrm{g}$ & 0.815 & 1.214 & 2.706 \\
\hline Fatty acids, total polyunsaturated & $\mathrm{g}$ & 0.772 & 1.150 & 2.563 \\
\hline Alpha Linoleic Acid & $\mathrm{g}$ & 0.049 & 0.073 & 0.163 \\
\hline EPA* $^{*}$ & $\mathrm{~g}$ & 0.069 & 0.103 & 0.229 \\
\hline $\mathrm{DPA}^{* *}$ & $\mathrm{~g}$ & 0.033 & 0.049 & 0.110 \\
\hline DHA $^{* * *}$ & $\mathrm{~g}$ & 0.252 & 0.041 & 0.837 \\
\hline Fatty acids, total trans & $\mathrm{g}$ & 0.019 & 0.028 & 0.063 \\
\hline Cholesterol & $\mathrm{mg}$ & 60 & 89 & 199 \\
\hline
\end{tabular}

USDA National Nutrient Database for Standard Reference Release 28 Full Report 15274, Fish, trout, brook, raw, New York State.

Report Date: December 03, 2015 13:53 EST.

Nutrient values and weights are for edible portion.

*Eicosapentaenoic acid.

** Docosapentaenoic acid.

*** Docosahexaenoic acid. 
well- characterized control composites (CC) with established tolerance limits developed for the NFNAP and/or certified reference materials (CRMs) were included in each analytical run to validate results (Phillips et al., 2006). CRMs were obtained from the National Institute of Standards and Technology (NIST, Gaithersburg, MD) (SRM ${ }^{\mathbb{R}} 2383$ Babyfood, SRM $^{\mathbb{R}} 2387$ Peanut Butter) and the Institute of Reference Materials and Methods (Geel, Belgium; purchased from RT Corp., Laramie, WY) (CRM 485 Lyophilized Mixed Vegetables, CRM 431 Lyophilized Brussel Sprouts). Results for the CCs and CRMs analyzed with the samples were compared to the certified ranges (for the CRM) and to established in-house tolerance limits (for the $\mathrm{CC}$ ) to validate the accuracy of the measurements.

\section{Results}

We successfully conducted a sampling and analysis of the nutritional content of wild-caught brook trout harvested in the legal spring fishing season in New York State and worked to have it included in the USDA National Nutrient Database for Standard Reference (SR). As a result, the general public and nutrition software companies now have access to the nutrition content of brook trout and Nutrition Fact Labels can be generated for recipes and foods that contain wild-caught brook trout. This was not possible prior to this work. The full nutrient profile can be found in SR Release 28 (Table 3). Our analysis found New York state brook trout to be a very lean source of protein and the percentage edible portion (mean \pm SE) was $42.6 \%$. \pm 0.94 .

\section{Discussion}

Now that brook trout is included in SR, recipes utilizing brook trout can reflect accurate nutrition information. Consumers can also access the SR to see nutritional information for brook trout according to various serving sizes. In 1990 the US Food and Drug Administration passed the Nutrition Labeling and Education Act which required all packaged foods to have nutrition labeling with basic per serving nutrition information for important nutrients in an easy-to-use format, the Nutrition Facts Label. Though the FDA does not require nutrition fact labels on meat and poultry, any packaged meat products (e.g., chicken pot pie) are required to have nutrition labeling, and many consumers look for nutrition information on recipes. SR is a primary database used to generate Nutrition Facts Labels. Consumers' ability to access the nutrition

Table 4

Comparison of the Nutritive Value of NY Wild Brook Trout vs. other Trout Species.

\begin{tabular}{|c|c|c|c|}
\hline Based on $100 \mathrm{~g}$ portion & $\begin{array}{l}\text { Wild Brook Trout NYS } \\
(\mathrm{n}=3)^{*}\end{array}$ & Wild Rainbow Trout & Domesticated Rainbow Trout \\
\hline \multicolumn{4}{|l|}{ Nutrients: } \\
\hline Energy $(\mathrm{kJ})$ & 458 & 498 & 589 \\
\hline Energy (kcal) & 110 & 119 & 141 \\
\hline Water & $75.7 \pm 0.5636$ & $71.87 \pm 0.8231$ & $\begin{array}{l}73.8 \pm 00.9402 \\
n=8\end{array}$ \\
\hline Protein (g) & $21.23 \pm 0.82$ & $\begin{array}{l}20.48 \pm 0.31 \\
n=28\end{array}$ & $\begin{array}{l}19.94 \pm 0.19 \\
n=8\end{array}$ \\
\hline Total fat(g) & $2.73 \pm 0.55$ & $\begin{array}{l}3.46 \pm 0.23 \\
n=50\end{array}$ & $\begin{array}{l}6.18 \pm 1.15 \\
n=8\end{array}$ \\
\hline Total saturated fatty acids ( $\mathrm{g}$ ) & $0.595 \pm 0.036$ & 0.722 & 1.383 \\
\hline Total mono- unsaturated fatty acids (g) & $0.815 \pm 0.11$ & 1.129 & 1.979 \\
\hline Total poly-unsaturated fatty acids (g) & $0.772 \pm 0.09$ & 1.237 & 1.507 \\
\hline Cholesterol (mg) & $60 \pm 1.99$ & $\begin{array}{l}59 \pm 2.95 \\
n=7\end{array}$ & $\begin{array}{l}59 \pm 1.18 \\
n=3\end{array}$ \\
\hline \multicolumn{4}{|l|}{ Minerals: } \\
\hline Ca (mg) & $25 \pm 7.03$ & $\begin{array}{l}67 \\
n=2\end{array}$ & $\begin{array}{l}25 \pm 3.00 \\
n=8\end{array}$ \\
\hline Fe (mg) & $0.38 \pm 0.019$ & $\begin{array}{l}0.70 \pm 0.31 \\
n=5\end{array}$ & $\begin{array}{l}0.31 \pm 0.02 \\
\mathrm{n}=8\end{array}$ \\
\hline $\mathrm{Mg}(\mathrm{mg})$ & $28 \pm 0.9262$ & $\begin{array}{l}31 \pm 0.4158 \\
n=22\end{array}$ & $\begin{array}{l}25 \pm 0.7333 \\
n=8\end{array}$ \\
\hline $\mathrm{P}(\mathrm{mg})$ & $246 \pm 6.03$ & $\begin{array}{l}271 \pm 8.12 \\
n=5\end{array}$ & $\begin{array}{l}226 \pm 6.59 \\
n=8\end{array}$ \\
\hline $\mathrm{K}(\mathrm{mg})$ & $417 \pm 9.5044$ & $\begin{array}{l}481 \pm 7.7773 \\
n=22\end{array}$ & $\begin{array}{l}377 \pm 15.2420 \\
\mathrm{n}=8\end{array}$ \\
\hline $\mathrm{Na}(\mathrm{mg})$ & $45 \pm 1.55$ & $\begin{array}{l}31 \pm 2.19 \\
n=22\end{array}$ & $\begin{array}{l}51 \pm 3.0 \\
n=8\end{array}$ \\
\hline $\mathrm{Zn}(\mathrm{mg})$ & $0.55 \pm 0.0117$ & 1.08 & $\begin{array}{l}0.45 \pm 0.0239 \\
\mathrm{n}=8\end{array}$ \\
\hline Vitamins: & & & \\
\hline Thiamin (mg) & $0.137 \pm 0.0145$ & $\begin{array}{l}0.123 \pm 0.0132 \\
n=5\end{array}$ & $\begin{array}{l}0.120 \pm 0.0346 \\
n=3\end{array}$ \\
\hline Riboflavin (mg) & $0.101 \pm 0.0104$ & $\begin{array}{l}0.105 \pm 0.0213 \\
n=5\end{array}$ & $\begin{array}{l}0.090 \pm 0.0058 \\
\mathrm{n}=3\end{array}$ \\
\hline Niacin $(\mathrm{mg})^{* *}$ & $5.293 \pm 0.64$ & $\begin{array}{l}5.384 \pm 0.28 \\
n=5\end{array}$ & $\begin{array}{l}5.567 \pm 0.4 \\
n=3\end{array}$ \\
\hline Vitamin B-6 (mg) & $0.273 \pm 0.41$ & $\begin{array}{l}0.406 \pm 0.17 \\
n=5\end{array}$ & $\begin{array}{l}0.340 \pm 0.31 \\
n=3\end{array}$ \\
\hline Vitamin B-12 ( $\mu \mathrm{g})$ & $2.77 \pm 0.32$ & $\begin{array}{l}4.45 \pm 0.56 \\
n=5\end{array}$ & $\begin{array}{l}4.30 \pm 0.4 \\
n=3\end{array}$ \\
\hline
\end{tabular}

Values are Mean \pm SE for $100 \mathrm{~g}$ of raw edible portion of fish.

${ }^{*} \mathrm{n}=3$ refers to 29 collected fish samples being aggregated into a composited sample size of 3 .

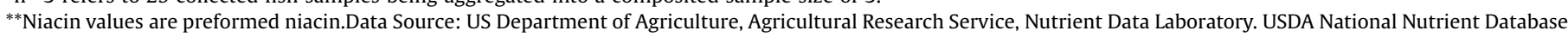

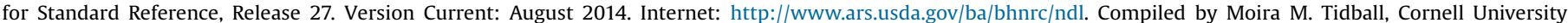
Cooperative Extension, March 2015. 
information for wild brook trout may help normalize and make more visible the importance of wild-caught foods as a healthy, locally-sourced meat

We found that brook trout has less energy (calories) and is leaner than other species of trout listed in SR (Table 4). Wild caught brook trout has 458 kilojoules (110 calories) based on 100-gram portion versus 498 kilojoules ( 119 calories) in wild rainbow trout, or 589 kilojoules (141 calories) in farmed rainbow trout based on the same $100-\mathrm{g}$ portion size. Wild brook trout has less than half the amount of fat found in farmed rainbow trout, 2.73 grams vs. $6.18 \mathrm{~g}$ in a $100 \mathrm{~g}$ portion. One may be able to assume, therefore, that wild caught brook trout will have less fat and calories than farm raised brook trout, but more comparative research is needed to fully understand the nutritional differences. Our research also showed wild caught brook trout has a slightly higher protein content compared to other trout species. Mineral and vitamin content is similar in SR for trout species, though calcium, iron, and zinc were higher in the wild rainbow trout than other listed trout species. The diet and living conditions of fish can have an impact in their nutrition content and quality. The leanness of the brook trout could be a function of seasonality and availability of foods for the fish. Fish were caught for this study from mid-May to mid-June, 2012 when they are very active and hungry after overwintering. It is possible that the brook trout sample used for this analysis reflects a leaner fat content as a result of the time of year that they were caught (Luzia et al., 2003). While researching the effect of climate on lipid content variation, Krzynowek (1985) reported that the fat contents of some fish species might vary by approximately $10 \%$ according to the season of capture. Henderson and Tocher (1987) listed 56 species of fresh water fish (mostly from temperate countries) whose fillets or muscles showed total lipid contents from 0.7 to $25.8 \%$ (wet basis). Also researching lipids, Lazos et al. (1989) studied 11 species of fresh water fish from Greece and found lipid contents in the 0.6 to $7.6 \%$ range. Luzia et al. (2003), found sardines collected during winter had the highest lipid contents (10.62). The sardine, the croaker, the tilápia and the curimbatá were not influenced by seasonality in terms of their total saturated and unsaturated fatty acid contents. The highest contents of eicosapentanoic acid (3.02 and 1.87\%) and docosahexaenoic acid (10.1 and $11.3 \%$ ) were found in the sardine. The shrimp presented the highest cholesterol contents with $165 \mathrm{mg} / 100 \mathrm{~g}$ in summer and $165 \mathrm{mg} / 100 \mathrm{~g}$ in winter (Luzia et al., 2003). The brook trout for our study were all collected in the spring.

A missed opportunity regarding this work has to do with carotenoid analysis and comparison. The flesh color of the fish that were caught and analyzed for our study were a pinkish-orange hue, indicative of beta-carotene content. Though we did not focus our analysis on this in our particular study, this is an area of great interest to some, and warrants further research. Carotenoids are being studied for their health benefits in fighting cancer and cardio disease, improving immune function, skin protection and cellular repair, along with eye function (Britton et al., 2009). The importance of consuming carotenoid-rich, orange-hued, vegetables and fruit is now a standard component of dietary recommendations (U.S. Department of Agriculture and U.S. Department of Health and Human Services, 2010; HealthCanada, 2011), and the discovery of the antitumor activity of vitamin A and Beta-carotene (Straub, 1987) has encouraged interest in marine carotenoids (Matsuno, 2001) as an additional dietary source. Future studies of wild caught trout should consider the carotenoid content in relation to the organge-hued flesh. The natural diet of wild brook trout contribute to a nutritious, lean fish, plus it is considered by many to be a delicacy (Leach, 1939). Our research elucidates the comparatively healthy nutrition content of brook trout, but we must add a caution to carefully follow angling regulations designed to maintain these fish in their native range, where their populations have been in decline due to habitat changes and acid rain. By contrast, in western North America this species is considered to be such a nuisance that anglers in states such as Oregon can harvest as many brook trout as they catch. Regulations pertaining to brook trout harvest differ from state to state, therefore anyone interested in harvesting wild brook trout should contact the state environmental conservation agency and follow the regulations regarding how many fish can be kept from certain waters and size requirements. Though brook trout require extremely high quality water and seldom contain levels of contaminants that are of concern for human consumption, one must still consider potential negative health effects of eating wild caught fish. As part of our research, we asked people what the barriers to consuming wild caught fish were and the area of most concern (60\%) was about the environmental quality where the fish were caught and associated food safety issues (55\%) (Tidball et al., 2014a, 2014b). Many state departments of health publish annual fish advisories indicating what waters are and are not safe to consume fish from, and offer advice and guidelines on the food safety aspects of consuming fish. For example, the New York State Department of Health offers an informational booklet, Health Advice on Eating Sportfish and Game, which is updated yearly. The fish in our study were all caught in waterways that were deemed safe for human fish consumption by the New York State Department of Health and Department of Environmental Conservation.

The focus of our research was on the nutrition content of brook trout.

This cold water species, as described earlier, has very specific requirements in terms of water quality, temperature, and $\mathrm{Ph}$, therefore, for this species, we did not find it necessary to specifically examine water quality or contaminants in our study. Replications of this kind of study with warm-water species would be well advised to consider water quality, however.

Other considerations relative to replication of a study such as this include guidance regarding acquiring samples. In our case (New York State), there are few bodies of water where brook trout can be successfully targeted by anglers outside of the May/June timeframe, when we conducted our sampling. However, should we have erroneously included in our sample the odd brook trout caught while ice fishing in February, we may have seen different results due to seasonal dietary changes among overwintering brook trout. Thus, if possible, sampling of wild caught fish should occur when anglers are most likely to target and catch them, so that the data most completely resemble what is most likely to be eaten.

It is also interesting to reflect on why so many wild-caught species are missing from large nutrient databases. There was a substantial cost associated with harvesting the samples of wild species according to precisely set protocols and conducting the laboratory research for nutrient content. Wild foods do not have industry-backing to pay for their nutritional analysis or requiring nutrition labeling. Therefore funding is a barrier to discovering the nutritional content of wild-caught foods.

\section{Conclusion}

The availability of nutritional data for brook trout contributes greater scientific understanding in the area of inquiry dealing with nutritional comparison of wild caught versus domestically raised foods, while addressing a cab in nutritional knowledge. It also adds legitimacy to claims that wild-caught brook trout is a healthful food. Though nutrition fact labeling is not required for meats, accurate nutrition labels can now be generated for recipes that include brook trout. We are now able to compare the major nutritional components of brook trout to other fish, yet the beta 
carotene content would require additional nutrient analysis. Still, many fish species that are legal to catch and consume do not have nutritional information in SR. The satisfaction of catching your own dinner, knowing exactly where your food comes from, plus the value of nature interaction may add to the nutritional health benefits of catching wild caught fish (Tidball et al., 2014a, 2014b). Further, because of where brook trout are generally found, anglers who seek and harvest brook trout may develop a greater appreciation of the surroundings within which they thrive, and may further engage fish habitat restoration projects and other conservation activities.

\section{Acknowledgements}

We would like to acknowledge generous funding from USDA Hatch Funds 2011-12-140: Leveraging the Locavore Movement: A Project to Explore Links Between Game Harvest and Community Food Security. We would like to thank the following individuals for assistance with collection of brook trout samples: Dan Josephson of the Department of Natural Resources at Cornell University, Adirondack Fishery Research Program, Little Moose Field Station; Dr. Richard Stedman of the Department of Natural Resources at Cornell University, Human Dimensions Research Unit, and Ms. Julie Nowlen. Thanks also to Katherine Phillips and staff at Food Analysis Laboratory and Control Center at Virginia Tech for compositing samples for nutrient analysis and Seneca County Cornell Cooperative Extension for coordinating project- related activities.

\section{References}

Ballin, N.Z., 2010. Authentication of meat and meat products. Meat Sci. 86 (3), 577587.

Britton, G., Liaaen-Jensen, S., Pfander, H., 2009. Carotenoids. Nutrition and Health, Volume 5. Birkhäuser Verlag, Basel.

Carlander, K.D., 1969. Handbook of Freshwater Fishery Biology. Iowa State University Press, Ames, IA.

Czeczuga, B., Czeczuga-Semeniuk, E., 1999. Comparative Studies of Carotenoids in Four Species of Crayfish. Crustaceana 72 (7), 693-700.

Czeczuga, B., Mironiuk, W., 1979. Investigations on carotenoids in insects 2. Water insects. Acta Hydrobiologica 22, 29-35.

Dunham, J.B., Adams, S.B., Schroeter, R.E., Novinger, D.C., 2002. Alien invasions in aquatic ecosystems: toward an understanding of brook trout invasions and potential impacts on inland cutthroat trout in western North America. Rev. Fish Biol. Fish. 12, 373-391.

Feltwell, J., Rothschild, M., 1974. Carotenoids in thirty-eight species of Lepidoptera. J. Zool. 174 (4), 441-465.

Goodwin, T.W., 1986. Metabolism, nutrition, and function of carotenoids. Annu. Rev. Nutr. 6 (1), 273-297.

Haytowitz, D.B., Pehrsson, P.R., Holden, J.M., 2008. The national food and analysis program: a decade of progress. J. Food Compos. Anal. 21, S94-S102.

HealthCanada, 2011. Eating Well with Canada's Food Guide. Health Canada.
Heath, J., Cipollini, D., Stireman Iii, J., 2013. The role of carotenoids and their derivatives in mediating interactions between insects and their environment. Arthropod-Plant Interact. 7 (1), 1-20.

Henderson, R.J., Tocher, D.R., 1987. The lipid composition and biochemistry of freshwater fish. Lipid Res. 26, 281-347.

Lazos, E.S., Aggelousis, G., Alexakis, A., 1989. Metal and proximate composition of the edible portion of 11 freshwater fish species. J. Food Composition Anal. 2, 371-381.

Leach, G.C., 1939. Artificial Propagation of Brook Trout and Rainbow Trout, with Notes on Three Other Species. U.S. Govt. Print. Off., Washington.

Love, M.S., 2011. Certainly More than You Want to Know About the Fishes of the Pacific Coast. Really Big Press, Santa Barbara, CA.

Luzia, L.A., Sampaio, G.R., Castellucci, C.M.N., Torres, E.A.F.S., 2003. The influence of season on the lipid profiles of five commercially important species of Brazilian fish. Food Chem. 83 (1), 93-97.

Matsuno, T., Ohkubo, M., Toriiminami, Y., Tsushima, M., Sakaguchi, S., Minami, T., Maoka, T., 1999. Carotenoids in food chain between freshwater fish and aquatic insects. Comp. Biochem. Physiol. B 124 (3), 341-345.

Matsuno, T., 2001. Aquatic animal carotenoids. Fish. Sci. 67 (5), 771-783.

Nislow, K.H., Lowe, W.H., 2003. Influences of logging history and stream ph on Brook Trout abundance in first-order streams in New Hampshire. Trans. Am. Fish. Soc. 132, 166-171.

Phillips, K.M., Patterson, K.Y., Rasor, A.R., Exler, J., Haytowitz, D.B., Holden, J.M., Pehrsson, P.R., 2006. The role of quality control and reference materials in the National Food and Nutrient Analysis Program. Anal. Bioanal. Chem. 384, 13411355.

Power, G., 1980. The brook charr, Salvelinus fontinalis. Charrs, salmonid fishes of the genus Salvelinus. In: Balon, E.K. (Ed.), The Hague. Dr. W. Junk Publishers, pp. 141-203.

Ray, C.C., 2014. What Determines the Color of Fish Flesh? The New York Times, New York, New York.

Ricker, W.E., 1930. Feeding habits of speckled trout in Ontario waters. Trans. Am. Fish. Soc. 60, 64-72.

Rimal, A., 2005. Meat labels: consumer attitude and meat consumption pattern. Int. J. Consum. Stud. 29 (1), 47-54.

Scott, W.B., Crossman, E.J., 1973. Freshwater Fishes of Canada. Fisheries Research Board of Canada: Bulletin, pp. 1-966.

Steine, G.R.O., Alfnes, F., RØRÅ, M.B., 2005. The effect of color on consumer WTP for farmed salmon. Mar. Resour. Econ. 20 (2), 211-219.

Steven, D.M., 1948. Studies on animal carotenoids: I. Carotenoids of the brown trout (Salmo trutta linn.). J. Exp. Biol. 25 (4), 369-387.

Straub, O., 1987. Key to Carotenoids. Birkhäuser Basel, Switzerland.

Tidball, K.G., Tidball, M., Larson, L.R., Curtis, P., Poindexter, L., Stedman, R.C., 2014a. Locavore Preferences for Wild Fish and Game: Implications for Wildlife Recreation in New York State. Human Dimensions Research Unit Series Publication Ithaca, NY, Department of Natural Resources, Cornell University.

Tidball, M.M., Tidball, K.G., Curtis, P., 2014b. The absence of wild game and fish species from the USDA national nutrient database for standard reference: addressing information gaps in wild caught foods. Ecol. Food Nutr. 53 (2), 142148.

Torrissen, O.J., Hardy, R.W., Shearer, K.D., 1989. Pigmenttaion of salmonidscarotenoid deposition and metabolism. Reviews in Aquatice Sciences 1 (2), 209-225.

US Department of Agriculture, U.S., U.S. Department of Health and Human Services, 2010. Dietary Guidelines for Americans, 7th edition U.S. Government Printing Office, Washington, DC, pp. 2010.

Veeck, A., 2010. Encounters with extreme foods: neophilic/neophobic tendencies and novel foods. J. Food Prod. Mark. 16 (2), 246-260.

Yamashita, E., 2013. Astaxanthin as a medical food. J. Funct. Foods Health Dis. 3 (7), 254-258. 